\title{
Transition and Adjustment of First-Year Student College in Dormitory: A Literature Review
}

\author{
Mukhroni $^{1}$, Sowiyah Sowiyah ${ }^{2}$, Hasan Hariri ${ }^{3}$ \\ ${ }^{1}$ Student Master of Educational Administration, Universitas Lampung \\ ${ }^{2,3}$ Faculty of Teacher Training and Education, Universitas Lampung
}

\begin{abstract}
The importance of transition and adjustment of students in the first year is interesting to study, and this paper examines the role of campus dormitories in assisting first year students in their transition and adjustment. There are several articles on reviews of transitions and adjustment of first-year students to be found. The purpose of this review is to find out the role of dormitories in the transition and adjustment period of first year students. Based on the results of a literature review, we found that campus dormitories can help students in transitioning and adjusting to their first year.
\end{abstract}

KEYWORDS: Adjustment, College, Dormitory, First-Year Student, Transition

\section{INTRODUCTION}

Transition and adjustment from high school to college is a complex process for almost all students in their first-year college. Transition is described as a "cultural shock involving significant social and psychological re-learning in the face of encounters with new ideas, new teachers and friends with sufficiently varied values and beliefs, new freedom and opportunities, and new academic, personal and social demands" [23]. Life transition, such as moving from home to college, create valuable opportunities for growth and change while also potentially increasing self-doubt and disappointment, and even encouraging self-defeating habits [10].

Entering college marks an important transition for many students. Entering college requires students to face many transitions, including changes in their life, academic environment, social environment, and adapting to their independence and responsibilities. Although many make this transition to college successfully, others experience long-term emotional mismatch and depression [19]. University as a place of learning is a place with great opportunities for students to develop their identity, morals and science. However, like any major life event, it too was accompanied by many significant changes. For example, supervision and protection of parents and teachers decreased, daily routines were changed, and individuals had to face challenges in academia, social relations, and other areas demanded by the new environment. As a result, the prevalence of adjustment disorder is relatively high among college students, especially in first and second year students [26]. Adjustment to college involves a variety of demands differing in kind and degree and requiring lot of coping responses or adjustments [23]. Because adjustment reflects the association between the individual and the environment, it is necessary to understand the transition, and adjustment to it, by examining characteristics of the environment and individuals endeavors to adjust within it [26].

During the transition period, first-year students will learn a new social life so that they are required to make adjustments and social adjustments. Students' ability to adapt during the first year of college can provide the basis for their adaptability to subsequent events during their life in college [7]. Previous research has suggested that students in their first-year face more difficulties in adjusting academically [23], if students are able to adapt themselves academically well, then all their abilities will adjust to the college environment [7]. Based on the results of these reviews, adjustment is the most important thing for students in their first-year of study.

In other research, [32] shows the role of parenting and current relationships with parents, in relation to psychological well-being variables, on student adjustment in university. However, what about the transition and adjustment of students who have to be far from their parents or live in a dormitory? There are still few studies on the transition period and adjustment of first-year students in college dormitories, so it is necessary to conduct research on how the transition and adjustment period of first-year students in college dormitories is necessary.

Dormitory as places for students to rest, study and interact play a very important role in student growth and development. Dormitories are the closest environment that can directly have a big influence on student development, with the programs offered in them, educational programs can directly influence the development of students, both in personality, academic abilities, and the development 


\section{International Journal of Current Science Research and Review}

ISSN: 2581-8341

Volume 04 Issue 08 August 2021

DOI: 10.47191/ijcsrr/V4-i8-07, Impact Factor: 5.825

of potential interests and talents of students [18]. Better dorm life can provide a sense of security and comfort for students so that they are better equipped to commit to academic studies and other more challenging assignments [5]. Based on this description, researchers are interested in exploring further about the role of dormitories in the transition and adjustment period of first-year students in college.

\section{METHOD}

This literature review focuses on the relationship between transition, first-year student adjustment, and college dormitory. The integrative review methodology was used to allow the inclusion of a wide variety of theoretical and empirical literature [25]. The review process draws from relevant literature using a transparent and reproducible search method, and the data obtained is analyzed and synthesized [29]. The review process began with a search engine, Google scholar, to search for articles with keywords: "transition, first-year student adjustment, and college dormitory". The search ranged was from 2000-2020 and it is identified a total of 17.300 studies and articles.

\section{INCLUSION AND EXCLUSION CRITERIA}

\section{Study Type}

The research design adopted in this scientific research is quantitative and qualitative methods.

2. Type of Intervention

The main intervention examined in scientific research is transition and adjustment first-year students.

Journals that match the inclusion criteria and have the theme of transition, adjustment and dormitory, for later review.

The criteria for the journals selected for review are journals in which there is a theme of transition, adjustment and dormitory.

The inclusion criteria for this article are shown in Table 1:

Table 1. Inclusion and exclusion criteria

\begin{tabular}{|l|l|}
\hline Inclusion criteria & Exclusion criteria \\
\hline Dormitory & Barracks \\
Adjustment & Workers dormitory \\
Transition & Different racial/ethnic \\
First-year of university & Boarding student \\
High school to college & Dissertations and theses \\
College/university & \\
\hline
\end{tabular}

Table 2. The results of the literature study table that was researched

\begin{tabular}{|c|c|c|c|c|c|c|c|}
\hline No & Title & $\begin{array}{l}\text { Author(s) } \\
\text { and year }\end{array}$ & $\begin{array}{l}\text { Type of } \\
\text { Organization }\end{array}$ & $\mathbf{N}$ & Country & Method & Result \\
\hline 1 & $\begin{array}{lr}\text { The Effect } & \text { of } \\
\text { Friends' } & \text { Social } \\
\text { Support on } & \text { New } \\
\text { Students' } & \text { Social } \\
\text { Adjustment } & \text { in } \\
\text { College } & \\
\text { Environment } & \end{array}$ & $\begin{array}{l}\text { Estiane } \\
\text { (2015) [7] }\end{array}$ & University & $\begin{array}{l}203 \\
\text { students }\end{array}$ & Indonesian & Quantitative & $\begin{array}{l}\text { There is the influence of } \\
\text { social support from } \\
\text { friends on the social } \\
\text { adjustment of new } \\
\text { students in the college } \\
\text { environment. }\end{array}$ \\
\hline 2 & $\begin{array}{l}\text { University } \\
\text { Belonging, } \\
\text { Friendship Quality, } \\
\text { and Psychological } \\
\text { Adjustment During } \\
\text { the Transition to } \\
\text { College }\end{array}$ & $\begin{array}{l}\text { Pittman } \\
\text { and } \\
\text { Richmond } \\
\text { (2008) } \\
{[19]}\end{array}$ & University & $\begin{array}{l}79 \\
\text { Students }\end{array}$ & USA & Quantitative & $\begin{array}{l}\text { The sense of university } \\
\text { ownership and quality } \\
\text { of friendship were } \\
\text { important factors in the } \\
\text { adjustment of students } \\
\text { to college during the } \\
\text { first-year. }\end{array}$ \\
\hline
\end{tabular}


ISSN: 2581-8341

Volume 04 Issue 08 August 2021

DOI: 10.47191/ijcsrr/V4-i8-07, Impact Factor: 5.825

\begin{tabular}{|c|c|c|c|c|c|c|c|}
\hline 3 & \begin{tabular}{lr}
\multicolumn{3}{l}{ First-Year Students' } \\
Adjustment & to \\
University Life & as \\
Function & of \\
Relationships & With \\
Parents &
\end{tabular} & $\begin{array}{l}\text { Wintre and } \\
\text { Yaffe } \\
(2000) \\
{[32]}\end{array}$ & University & $\begin{array}{l}408 \text { first- } \\
\text { year } \\
\text { students }\end{array}$ & $\begin{array}{l}\text { Canada, } \\
\text { North } \\
\text { America }\end{array}$ & Quantitative & $\begin{array}{l}\text { The psychological well- } \\
\text { being had an influence } \\
\text { on the adjustment of } \\
\text { first-year students at } \\
\text { university. }\end{array}$ \\
\hline 4 & $\begin{array}{l}\text { Adjustment and } \\
\text { Emotion Maturity } \\
\text { Among First-year } \\
\text { College Student }\end{array}$ & $\begin{array}{l}\text { Sharma } \\
(2012) \\
{[23]}\end{array}$ & University & $\begin{array}{l}100 \\
\text { students }\end{array}$ & India & $\begin{array}{l}\text { Quantitative } \\
\text { and } \\
\text { qualitative }\end{array}$ & $\begin{array}{l}\text { The First-year students } \\
\text { are not mature enough } \\
\text { emotional and thus face } \\
\text { difficulty in adjusting } \\
\text { emotions with changing } \\
\text { environmental demands } \\
\text { compared to final year } \\
\text { students. }\end{array}$ \\
\hline 5 & $\begin{array}{l}\text { Social Support : } \\
\text { Relations to Coping } \\
\text { and Adjustment } \\
\text { During the } \\
\text { Transition to } \\
\text { University in the } \\
\text { People's Republic } \\
\text { of China }\end{array}$ & $\begin{array}{l}\text { Tao, Dong } \\
\text { et al. } \\
(2000) \\
{[26]}\end{array}$ & University & $\begin{array}{l}106 \\
\text { students }\end{array}$ & China & Quantitative & $\begin{array}{l}\text { that overall social } \\
\text { support at the start of } \\
\text { the first semester is } \\
\text { associated with } \\
\text { adjustments at the end } \\
\text { of the first semester } \\
\text { either on a basis directly } \\
\text { or indirectly through } \\
\text { less negative coping } \\
\text { patterns and more } \\
\text { positive coping in } \\
\text { among those who } \\
\text { reported greater } \\
\text { perceived } \\
\text { support social }\end{array}$ \\
\hline 6 & $\begin{array}{l}\text { Consultation, } \\
\text { Contribution, and } \\
\text { Shared Benefits-The } \\
\text { Golden Principle of } \\
\text { Creating a Better } \\
\text { Dormitory Life for } \\
\text { College Student }\end{array}$ & $\begin{array}{l}\text { Dan-Ping } \\
\text { (2018) [5] }\end{array}$ & University & & China & Descriptive & $\begin{array}{l}\text { In order to create a } \\
\text { better dorm life, } \\
\text { students must first raise } \\
\text { awareness of "Broad } \\
\text { Consultation", and then } \\
\text { increase the } \\
\text { "contribution" } \\
\text { mechanism. }\end{array}$ \\
\hline 7 & $\begin{array}{l}\text { High School to } \\
\text { College Transition : } \\
\text { A Profile of the } \\
\text { Stressors, Physical } \\
\text { and Psychological } \\
\text { Health Issues That } \\
\text { Affect the First- } \\
\text { Year On-Campus } \\
\text { College Student }\end{array}$ & $\begin{array}{l}\text { Hicks and } \\
\text { Heastie } \\
(2008) \\
{[10]}\end{array}$ & University & $\begin{array}{l}514 \\
\text { students }\end{array}$ & $\begin{array}{l}\text { North } \\
\text { Carolina }\end{array}$ & Quantitative & $\begin{array}{l}\text { The first-year freshmen } \\
\text { may have adjustment } \\
\text { problems and } \\
\text { experience unwanted } \\
\text { stress and } \\
\text { psychological problems } \\
\text { during the first-year on } \\
\text { campus }\end{array}$ \\
\hline
\end{tabular}


ISSN: 2581-8341

Volume 04 Issue 08 August 2021

DOI: 10.47191/ijcsrr/V4-i8-07, Impact Factor: 5.825

\begin{tabular}{|c|c|c|c|c|c|c|c|}
\hline 8 & $\begin{array}{l}\text { Behavioral Risks } \\
\text { during the } \\
\text { Transition from } \\
\text { High School to } \\
\text { College }\end{array}$ & $\begin{array}{l}\text { Fromme, } \\
\text { Corbin et } \\
\text { al. (2008) } \\
\text { [9] }\end{array}$ & University & $\begin{array}{l}2210 \\
\text { students }\end{array}$ & $\begin{array}{l}\text { Southwest } \\
\text { United } \\
\text { States }\end{array}$ & Quantitative & $\begin{array}{l}\text { Behavior } \\
\text { during the transition } \\
\text { period, } \\
\text { during the first-year of } \\
\text { college, are due to } \\
\text { decreased } \\
\text { supervision adult } \\
\text { freedom to live outside } \\
\text { the home. Colleges may } \\
\text { also consider policies } \\
\text { that promote greater } \\
\text { supervision } \\
\text { dormitories }\end{array}$ \\
\hline 9 & $\begin{array}{l}\text { Estimating the } \\
\text { effects of dormitory } \\
\text { living on student } \\
\text { performance }\end{array}$ & $\begin{array}{l}\text { Murray } \\
\text { and Arajuo } \\
(2010) \\
{[15]}\end{array}$ & University & $\begin{array}{l}363 \\
\text { students }\end{array}$ & USA & Quantitative & $\begin{array}{l}\text { There is an increase in } \\
\text { the achievement of } \\
\text { GPA for students living } \\
\text { in dormitories. }\end{array}$ \\
\hline 10 & $\begin{array}{l}\text { Relationship } \\
\text { between Coping and } \\
\text { University } \\
\text { Adjustment and } \\
\text { Academic } \\
\text { Achievement } \\
\text { amongst First-year } \\
\text { Undergraduates in a } \\
\text { Malaysian Public } \\
\text { University }\end{array}$ & $\begin{array}{l}\text { Abdullah, } \\
\text { Elias et al. } \\
(2010)[1]\end{array}$ & University & $\begin{array}{l}250 \\
\text { students }\end{array}$ & Malaysia & Quantitative & $\begin{array}{l}\text { The findings of this } \\
\text { study indicate that there } \\
\text { is a significant and } \\
\text { positive relationship } \\
\text { between student coping } \\
\text { with overall university } \\
\text { adjustment, academic } \\
\text { adjustment, social } \\
\text { adjustment, personal- } \\
\text { emotional adjustment, } \\
\text { student engagement } \\
\text { with university, and } \\
\text { academic achievement. }\end{array}$ \\
\hline 11 & $\begin{array}{l}\text { Social Support, Self- } \\
\text { Esteem, and Stress } \\
\text { as Predictors of } \\
\text { Adjustment to } \\
\text { University Among } \\
\text { First-Year } \\
\text { Undergraduates }\end{array}$ & $\begin{array}{l}\text { Friedlande } \\
\text { r, Reid et } \\
\text { al. (2007) } \\
\text { [8] }\end{array}$ & University & $\begin{array}{l}115 \\
\text { students }\end{array}$ & $\begin{array}{l}\text { Canada, } \\
\text { North } \\
\text { America }\end{array}$ & Quantitative & $\begin{array}{l}\text { Consistently self- } \\
\text { perceived stress } \\
\text { changes be a major } \\
\text { predictor of adjustment. } \\
\text { Social support is an } \\
\text { important protective } \\
\text { factor assist students in } \\
\text { making the transition to } \\
\text { university }\end{array}$ \\
\hline 12 & \begin{tabular}{lr}
\multicolumn{2}{l}{ Formation of Socio- } \\
Academic & Climate \\
in & Student \\
Dormitory &
\end{tabular} & $\begin{array}{l}\text { Utari, } \\
\text { Sutapa et } \\
\text { al. (2014) } \\
\text { [31] }\end{array}$ & University & $\begin{array}{l}132 \\
\text { students }\end{array}$ & Indonesian & Quantitative & $\begin{array}{l}\text { Creates a socio- } \\
\text { academic climate can } \\
\text { be identified aspects } \\
\text { that are components in } \\
\text { the development of the } \\
\text { social academic climate } \\
\text { in student flats, that is: } \\
\text { a) occupant aspects, b) }\end{array}$ \\
\hline
\end{tabular}


ISSN: 2581-8341

Volume 04 Issue 08 August 2021

DOI: 10.47191/ijcsrr/V4-i8-07, Impact Factor: 5.825

\begin{tabular}{|c|c|c|c|c|c|c|c|}
\hline & & & & & & & $\begin{array}{l}\text { aspects nanny, c) } \\
\text { aspects of the } \\
\text { development system, d) } \\
\text { aspects of the facility, } \\
\text { and e) organizational } \\
\text { aspects }\end{array}$ \\
\hline 13 & $\begin{array}{l}\text { Achievement } \\
\text { Motivation and Self- } \\
\text { Efficacy in Relation } \\
\text { to Adjustment } \\
\text { among University } \\
\text { Students }\end{array}$ & $\begin{array}{l}\text { Elias, } \\
\text { Noordin et } \\
\text { al. (2010) } \\
{[6]}\end{array}$ & University & $\begin{array}{l}178 \\
\text { students }\end{array}$ & Malaysia & Quantitative & $\begin{array}{l}\text { The students with high } \\
\text { achievement } \\
\text { motivation tend to be } \\
\text { confident, responsible } \\
\text { and have positive } \\
\text { beliefs in themselves }\end{array}$ \\
\hline 14 & $\begin{array}{lr}\text { Coping } & \text { Styles, } \\
\text { Social Support, } \\
\text { Relational } & \text { Self- } \\
\text { Construal, } & \text { and } \\
\text { Resilience } & \text { in } \\
\text { Predicting } & \text { Students' } \\
\text { Adjustment } & \text { to } \\
\text { University Life }\end{array}$ & $\begin{array}{l}\text { Rahat and } \\
\text { İlhan } \\
(2016) \\
{[20]}\end{array}$ & University & $\begin{array}{l}527 \\
\text { students }\end{array}$ & Turkey & Quantitative & $\begin{array}{l}\text { The optimism in } \\
\text { freshmen was one of the } \\
\text { factors that facilitated } \\
\text { the adjustment process } \\
\text { to university life. The } \\
\text { coping styles were the } \\
\text { most effective } \\
\text { predictors of personal } \\
\text { adjustment from among } \\
\text { all subdimensions of } \\
\text { adjustment to university } \\
\text { life, and social support } \\
\text { sources were the most } \\
\text { effective predictors of } \\
\text { social adjustment. }\end{array}$ \\
\hline 15 & $\begin{array}{l}\text { Transitioning From } \\
\text { High School to } \\
\text { College: Relations } \\
\text { of Social Support, } \\
\text { Ego-Resiliency, and } \\
\text { Maladjustment } \\
\text { During Emerging } \\
\text { Adulthood }\end{array}$ & $\begin{array}{l}\text { Taylor, } \\
\text { Doane et } \\
\text { al. (2014) } \\
{[27]}\end{array}$ & University & $\begin{array}{l}(\mathrm{Ns}=82, \\
76, \text { and } 71 \\
\text { at Times } \\
1,2 \text {, and } \\
3, \\
\text { respective } \\
\text { ly) }\end{array}$ & USA & Quantitative & $\begin{array}{l}\text { Internalizing symptoms } \\
\text { were concurrently } \\
\text { negatively correlated } \\
\text { with perceived social } \\
\text { support from friends } \\
\text { and family as well as } \\
\text { with ego-resiliency, and } \\
\text { ego-resiliency was } \\
\text { positively, concurrently } \\
\text { correlated } \\
\text { perceived with } \\
\text { support from friends. }\end{array}$ \\
\hline 16 & $\begin{array}{l}\text { Homesickness and } \\
\text { Adjustment in } \\
\text { University Students }\end{array}$ & $\begin{array}{l}\text { Thurber } \\
\text { and } \\
\text { Walton } \\
(2012) \\
{[28]}\end{array}$ & University & $\begin{array}{l}500 \\
\text { female } \\
\text { students }\end{array}$ & USA & Quantitative & $\begin{array}{l}\text { A comprehensive } \\
\text { school-based anti- } \\
\text { homesickness program } \\
\text { that customized each of } \\
\text { the prevention and } \\
\text { treatment } \\
\text { recommendations } \\
\text { above would likely see }\end{array}$ \\
\hline
\end{tabular}


ISSN: 2581-8341

Volume 04 Issue 08 August 2021

DOI: 10.47191/ijcsrr/V4-i8-07, Impact Factor: 5.825

\begin{tabular}{|c|c|c|c|c|c|c|c|}
\hline & & & & & & & \begin{tabular}{l}
\multicolumn{2}{c}{ a dramatic reduction in } \\
the prevalence and \\
intensity \\
homesickness \\
campus.
\end{tabular} \\
\hline 17 & $\begin{array}{l}\text { The effectiveness of } \\
\text { solution-focused } \\
\text { brief therapy on } \\
\text { increasing social } \\
\text { adjustment of } \\
\text { female students } \\
\text { residing in Tehran } \\
\text { University } \\
\text { dormitories }\end{array}$ & $\begin{array}{l}\text { Saffarpoor } \\
\text { Farahbakh } \\
\text { sh et al. } \\
(2011) \\
{[22]}\end{array}$ & University & $\begin{array}{l}500 \\
\text { female } \\
\text { students } \\
\text { as sample }\end{array}$ & Iran & Quantitative & $\begin{array}{l}\text { After participating in } \\
\text { sessions led by a } \\
\text { therapist, they will find } \\
\text { possible solutions for } \\
\text { the social problems } \\
\text { they have faced, in } \\
\text { relating to their new } \\
\text { environment and being } \\
\text { away from their family. }\end{array}$ \\
\hline 18 & $\begin{array}{l}\text { Living-Learning } \\
\text { Programs And First- } \\
\text { Generation College } \\
\text { Students' } \\
\text { Academic And } \\
\text { Social Transition To } \\
\text { To College }\end{array}$ & $\begin{array}{l}\text { Inkelas, } \\
\text { Daver et } \\
\text { al. (2007) } \\
{[12]}\end{array}$ & University & $\begin{array}{l}33 \\
\text { campuses } \\
\text { who had } \\
\text { first- } \\
\text { generatio } \\
\mathrm{n} \\
\text { responden } \\
\text { ts }\end{array}$ & Colombia & Quantitative & $\begin{array}{l}\text { First-generation } \mathrm{L} / \mathrm{L} \\
\text { program students had a } \\
\text { statistically significant } \\
\text { higher mean score on } \\
\text { perceptions of ease with } \\
\text { their academic } \\
\text { transition to college }\end{array}$ \\
\hline 19 & $\begin{array}{l}\text { Identity Status, } \\
\text { Identity Processing } \\
\text { Style, and the } \\
\text { Transition } \\
\text { University }\end{array}$ & $\begin{array}{l}\text { Berzonsky } \\
\text { and Kuk } \\
\text { (2000) [2] }\end{array}$ & University & $\begin{array}{l}363 \\
\text { students }\end{array}$ & USA & Quantitative & $\begin{array}{l}\text { The present results } \\
\text { suggest that students' } \\
\text { levels of personal } \\
\text { identity development } \\
\text { may play a role in the } \\
\text { extent to which they } \\
\text { experience difficulty } \\
\text { and problems in making } \\
\text { the transition to } \\
\text { university. }\end{array}$ \\
\hline 20 & $\begin{array}{l}\text { The Impact of } \\
\text { Residence Design } \\
\text { on Freshman } \\
\text { Outcomes: } \\
\text { Dormitories Versus } \\
\text { Suite-Style } \\
\text { Residences }\end{array}$ & $\begin{array}{l}\text { Rodger } \\
\text { and } \\
\text { Johnson } \\
(2005) \\
{[21]}\end{array}$ & University & $\begin{array}{l}909 \\
\text { students } \\
(159 \\
\text { students } \\
\text { living in } \\
\text { suite- } \\
\text { style } \\
\text { accommo } \\
\text { dations, } \\
\text { and } 750 \\
\text { students } \\
\text { living in } \\
\text { dormstyle } \\
\text { accommo } \\
\text { dations) }\end{array}$ & $\begin{array}{l}\text { Canada, } \\
\text { North } \\
\text { America }\end{array}$ & Quantitative & $\begin{array}{l}\text { The demonstration that } \\
\text { students living in suite- } \\
\text { style residences report a } \\
\text { significantly higher } \\
\text { sense of belonging. } \\
\text { Furthermore, students } \\
\text { living in suite-style } \\
\text { buildings demonstrate a } \\
\text { significantly higher } \\
\text { activity level than their } \\
\text { peers living in dorm- } \\
\text { style residences. }\end{array}$ \\
\hline
\end{tabular}


ISSN: 2581-8341

Volume 04 Issue 08 August 2021

DOI: 10.47191/ijcsrr/V4-i8-07, Impact Factor: 5.825

\begin{tabular}{|c|c|c|c|c|c|c|c|}
\hline 21 & $\begin{array}{l}\text { Predicting } \\
\text { Transition And } \\
\text { Adjustment To } \\
\text { College: Biomedical } \\
\text { And Behavioral } \\
\text { Science Aspirants' } \\
\text { And Minority } \\
\text { Students' First Year } \\
\text { Of College }\end{array}$ & $\begin{array}{l}\text { Hurtado, } \\
\text { Han et al. } \\
\text { (2007) } \\
{[11]}\end{array}$ & University & $\begin{array}{l}\text { sample of } \\
5049 \\
\text { students } \\
\text { comprise } \\
\text { d of URM } \\
\text { science } \\
\text { majors } \\
(1851) \text {, } \\
\text { White/As } \\
\text { ian } \\
\text { science } \\
\text { majors } \\
(1366) \text {, } \\
\text { and URM } \\
\text { nonscience } \\
\text { majors } \\
\text { (1832) }\end{array}$ & USA & Quantitative & $\begin{array}{l}\text { this study confirms that } \\
\text { academic adjustment } \\
\text { and sense of belonging } \\
\text { are strongly linked for } \\
\text { all students in the first } \\
\text { year of college }\end{array}$ \\
\hline 22 & $\begin{array}{l}\text { First Year Students' } \\
\text { Engagement at the } \\
\text { University }\end{array}$ & $\begin{array}{l}\text { Mehdinez } \\
\text { had (2011) } \\
{[13]}\end{array}$ & University & $\begin{array}{l}551 \\
\text { students }\end{array}$ & Iran & Quantitative & $\begin{array}{l}\text { The highest correlation } \\
\text { is related to the online } \\
\text { engagement scale with } \\
\text { the intellectual } \\
\text { engagement, the } \\
\text { transition engagement } \\
\text { with the student-staff } \\
\text { engagement, peer } \\
\text { engagement scale with } \\
\text { the academic } \\
\text { engagement, and the } \\
\text { beyond-class } \\
\text { engagement scale with } \\
\text { the online engagement. }\end{array}$ \\
\hline 23 & $\begin{array}{l}\text { The Importance of } \\
\text { Friends Friendship } \\
\text { and Adjustment } \\
\text { Among 1st-Year } \\
\text { University Students }\end{array}$ & $\begin{array}{l}\text { Buote, } \\
\text { Pancer et } \\
\text { al. (2007) } \\
{[4]}\end{array}$ & University & $\begin{array}{l}702 \\
\text { students }\end{array}$ & $\begin{array}{l}\text { Canada, } \\
\text { North } \\
\text { America }\end{array}$ & $\begin{array}{l}\text { qualitative } \\
\text { and } \\
\text { quantitative }\end{array}$ & $\begin{array}{l}\text { Results indicated a } \\
\text { significant positive } \\
\text { relation between quality } \\
\text { of new friendships and } \\
\text { adjustment } \\
\text { university; to } \\
\text { association this } \\
\text { stronger for students } \\
\text { living in residence than } \\
\text { for those commuting to } \\
\text { university. }\end{array}$ \\
\hline 24 & $\begin{array}{l}\text { The Transition To } \\
\text { University: } \\
\text { Adaptation And } \\
\text { Adjustment }\end{array}$ & $\begin{array}{l}\text { Smith } \\
(2008) \\
{[24]}\end{array}$ & University & $\begin{array}{l}229 \\
\text { students }\end{array}$ & $\begin{array}{l}\text { Canada, } \\
\text { North } \\
\text { America }\end{array}$ & Quantitative & $\begin{array}{l}\text { During the first } \\
\text { semester, } \\
\text { transitions and better } \\
\text { adjustment were largely } \\
\text { predicted by more }\end{array}$ \\
\hline
\end{tabular}


ISSN: 2581-8341

Volume 04 Issue 08 August 2021

DOI: 10.47191/ijcsrr/V4-i8-07, Impact Factor: 5.825

\begin{tabular}{|c|c|c|c|c|c|c|c|}
\hline & & & & & & & $\begin{array}{l}\text { adaptive coping, good } \\
\text { social support, better } \\
\text { grades and fewer daily } \\
\text { hassles. For women, } \\
\text { second semester } \\
\text { transition experiences } \\
\text { and adjustment } \\
\text { measures were strongly } \\
\text { predicted by the same } \\
\text { measures as observed in } \\
\text { the first semester. }\end{array}$ \\
\hline 25 & $\begin{array}{l}\text { Friendsickness in } \\
\text { the Transition to } \\
\text { College: Precollege } \\
\text { Predictors and } \\
\text { College Adjustment } \\
\text { Correlates }\end{array}$ & $\begin{array}{l}\text { Paul and } \\
\text { Brier } \\
(2001) \\
{[17]}\end{array}$ & University & $\begin{array}{l}70 \\
\text { students }\end{array}$ & USA & Quantitative & $\begin{array}{l}\text { The results of the } \\
\text { present study suggest } \\
\text { that students who are } \\
\text { highly preoccupied } \\
\text { with and concerned } \\
\text { about their precollege } \\
\text { friendships exhibit } \\
\text { poorer adjustment to } \\
\text { college along a number } \\
\text { of dimensions }\end{array}$ \\
\hline 26 & $\begin{array}{l}\text { Homesickness in } \\
\text { Socially anxious } \\
\text { first year college } \\
\text { students }\end{array}$ & $\begin{array}{l}\text { Urani, } \\
\text { Miller et } \\
\text { al. (2003) } \\
\text { [30] }\end{array}$ & University & $\begin{array}{l}105 \\
\text { students }\end{array}$ & USA & Quantitative & $\begin{array}{l}\text { the result indicated that } \\
\text { the transition to } \\
\text { university life can be } \\
\text { very stressfull for the } \\
\text { student, resulting in } \\
\text { homesickness, and } \\
\text { psychological } \\
\text { disturbance }\end{array}$ \\
\hline 27 & $\begin{array}{l}\text { Social Class and } \\
\text { Belonging: } \\
\text { Implications for } \\
\text { College Adjustment }\end{array}$ & $\begin{array}{l}\text { Ostrove } \\
\text { and Long } \\
(2007) \\
{[16]}\end{array}$ & University & $\begin{array}{l}252 \\
\text { students }\end{array}$ & USA & Quantitative & $\begin{array}{l}\text { Both objective } \\
\text { subjective and } \\
\text { background class } \\
\text { significantly related to } \\
\text { sense of belonging and } \\
\text { to academic } \\
\text { adjustment; subjective } \\
\text { class background was } \\
\text { also significantly } \\
\text { related to social } \\
\text { adjustment, and } \\
\text { objective } \\
\text { background was weakly } \\
\text { correlated with GPA }\end{array}$ \\
\hline 28 & $\begin{array}{lr}\text { The Role } & \text { of } \\
\text { Organized } & \\
\text { Activities } & \text { in } \\
\text { Facilitating } & \text { Social }\end{array}$ & $\begin{array}{l}\text { Bohnert, } \\
\text { Aikins et } \\
\text { al. (2007) } \\
{[3]}\end{array}$ & University & $\begin{array}{l}85 \\
\text { adolescen } \\
\text { ts }\end{array}$ & USA & Quantitative & $\begin{array}{l}\text { These findings also } \\
\text { suggest that the relation } \\
\text { between change in best } \\
\text { friendships and activity }\end{array}$ \\
\hline
\end{tabular}




\section{International Journal of Current Science Research and Review}

ISSN: 2581-8341

Volume 04 Issue 08 August 2021

DOI: 10.47191/ijcsrr/V4-i8-07, Impact Factor: 5.825

IJCSRR@ 2021

www.ijesrr.org

\begin{tabular}{|c|c|c|c|c|c|c|c|}
\hline & $\begin{array}{l}\text { Adaptation Across } \\
\text { the Transition to } \\
\text { College }\end{array}$ & & & & & & $\begin{array}{l}\text { involvement in } \\
\text { emerging adulthood } \\
\text { may be mediated by } \\
\text { social motivations. }\end{array}$ \\
\hline 29 & $\begin{array}{l}\text { Student Dormitory } \\
\text { as a Character- } \\
\text { Based Education in } \\
\text { Higher Schools } \\
\text { (A Case Study at } \\
\text { Telkom University } \\
\text { Dormitory - } \\
\text { Bandung) }\end{array}$ & $\begin{array}{l}\text { Murdowo, } \\
\text { Budimans } \\
\text { yah et al. } \\
(2017) \\
{[14]}\end{array}$ & University & $\begin{array}{l}30 \\
\text { students }\end{array}$ & Indonesia & Qualitative & $\begin{array}{l}\text { Dormitory's } \\
\text { supervision and activity } \\
\text { developed the aspects } \\
\text { of adaptive, spiritual, } \\
\text { academic and social } \\
\text { (ASAS); assessment } \\
\text { method to gain Student } \\
\text { Activity Transcript } \\
\text { point or Transkrip } \\
\text { Aktivitas } \\
\text { Kemahasiswaan (TAK) } \\
\text { point; well-organized } \\
\text { policy and program on } \\
\text { the level of institution, } \\
\text { supervision, and } \\
\text { program organizer. }\end{array}$ \\
\hline
\end{tabular}

\section{RESULTS AND DISCUSSION}

This section reports the main findings of the articles reviewed. The analysis shows that most articles focus on successful transitions and adjustments beginning when students first come into contact with college. Almost all studies show that freshmen are less mature emotionally, and have difficulty adjusting emotionally and socially to the demands of a changing environment. Many international studies on the transition to college highlight the importance of the transition period, research findings suggest that first-year freshmen may have adjustment problems and experience unwanted stress and psychological problems during the first-year on campus (Hicks and Heastie 2008). The sense of belonging to a college and the quality of friendships have a positive influence on adjustment and transition in college (Pittman and Richmond 2008). Therefore, it is important to help students, especially first year students, identify various coping strategies to deal with stress during their transition to college (Abdullah, Elias et al. 2010) one of which is through the boarding program.

For students who live in dormitories, they consider dormitories an important part of a better campus life, because they spend most of their time on campus. As a place to rest, learn and interact, dormitories are a vital place for the quality of student life. Directly, dormitories can develop adaptive, spiritual, academic and social aspects (Murdowo, Budimansyah et al. 2017). From the writer's point of view, a good dorm life includes the following aspects: first, the residents of the hostel feel safe, which provides the foundation for a good dorm life because safety is the top priority in every place. Second, the hostel provides a clean and tidy environment. Third, the atmosphere is comfortable and pleasant in the dormitory because the hostel is like a house that provides warmth and comfort for its members. Fourth, dormitory residents enjoy a healthy lifestyle and are willing to face challenges that can improve themselves through activities in the dormitory.

In general, it can be concluded that the dormitory can play a key role in helping new students to overcome the problems of adjustment and transition through the program services in the hostel.

Like other studies, this review has limitations. First, the review of articles is only in Indonesian and English so that other studies are not reviewed due to the limitations of the author. Second, the scope of the articles reviewed is still very limited, in this paper the scope is only limited to research conducted in some countries in the Americas and some countries in the Asian continent, while the variations in the countries of the Americas and Asia that are reviewed are still lacking. A final limitation is that no single measure can be compared between studies. This review is still minimal and even challenging to find a lot of literature that combines the 


\section{International Journal of Current Science Research and Review}

ISSN: 2581-8341

Volume 04 Issue 08 August 2021

DOI: 10.47191/ijcsrr/V4-i8-07, Impact Factor: 5.825

IJCSRR@ 2021

WwW.ijcsrr.org

variables of dormitory role, transition period and adjustment of first year students. The next step that needs to be done is a followup study (other research) - related to research on the role of dormitories in the transition and adjustment period of first-year students.

\section{REFERENCES}

1. Abdullah, M. C., et al. (2010). "Relationship between coping and university adjustment and academic achievement amongst first year undergraduates in a Malaysian public university." International Journal of Arts and Sciences 3(11): 379-392.

2. Berzonsky, M. D. and L. S. Kuk (2000). "Identity status, identity processing style, and the transition to university." Journal of adolescent research 15(1): 81-98.

3. Bohnert, A. M., et al. (2007). "The role of organized activities in facilitating social adaptation across the transition to college." Journal of adolescent research 22(2): 189-208.

4. Buote, V. M., et al. (2007). "The importance of friends: Friendship and adjustment among 1st-year university students." Journal of adolescent research 22(6): 665-689.

5. Dan-Ping, W. (2018). "Consultation, Contribution and Shared Benefits-The Golden Principle of Creating a Better Dormitory Life for College Students." DEStech Transactions on Economics, Business and Management (eced).

6. Elias, H., et al. (2010). "Achievement motivation and self-efficacy in relation to adjustment among university students." Journal of social sciences 6(3): 333-339.

7. Estiane, U. (2015). "Pengaruh dukungan sosial sahabat terhadap penyesuaian sosial mahasiswa baru di lingkungan perguruan tinggi." Jurnal Psikologi Klinis dan Kesehatan Mental 4(1): 29-40.

8. Friedlander, L. J., et al. (2007). "Social support, self-esteem, and stress as predictors of adjustment to university among first-year undergraduates." Journal of college student development 48(3): 259-274.

9. Fromme, K., et al. (2008). "Behavioral risks during the transition from high school to college." Developmental psychology 44(5): 1497.

10. Hicks, T. and S. Heastie (2008). "High school to college transition: A profile of the stressors, physical and psychological health issues that affect the first-year on-campus college student."

11. Hurtado, S., et al. (2007). "Predicting transition and adjustment to college: Biomedical and behavioral science aspirants' and minority students' first year of college." Research in Higher education 48(7): 841-887.

12. Inkelas, K. K., et al. (2007). "Living-learning programs and first-generation college students' academic and social transition to college." Research in Higher education 48(4): 403-434.

13. Mehdinezhad, V. (2011). "First Year Students' Engagement at the University." International Online Journal of Educational Sciences 3(1).

14. Murdowo, D., et al. (2017). "Student Dormitory as a Character-Based Education in Higher Schools (A Case Study at Telkom University Dormitory-Bandung)."

15. Murray, J. and P. Arajuo (2010). Estimating the Effects of Dormitory Living on Student Performance. Proceeding of the 2009 Southern Economics Conference, cited in Pat-Mbano, EC, Alaka, IN, and Okeoma, IO (2012), "Examining the Physio, psycho, and socioeconomic implications of non residency policy on Imo State University Students", Canadian Social Sciences.

16. Ostrove, J. M. and S. M. Long (2007). "Social class and belonging: Implications for college adjustment." The Review of Higher Education 30(4): 363-389.

17. Paul, E. L. and S. Brier (2001). "Friendsickness in the transition to college: Precollege predictors and college adjustment correlates." Journal of Counseling \& Development 79(1): 77-89.

18. Pertiwi, D. A. (2017). "Implementasi Program Pendidikan Asrama Dalam Meningkatkan Kecerdasan Spiritual Santriwati Di Asrama Bahasa Arab Hubbul Wathan Medan." At-Tazakki: Jurnal Kajian Ilmu Pendidikan Islam dan Humaniora 1(2): 101-121.

19. Pittman, L. D. and A. Richmond (2008). "University belonging, friendship quality, and psychological adjustment during the transition to college." The Journal of Experimental Education 76(4): 343-362.

20. Rahat, E. and T. İlhan (2016). "Coping styles, social support, relational self-construal, and resilience in predicting students' adjustment to university life." Educational Sciences: Theory \& Practice 16(1). 


\section{International Journal of Current Science Research and Review}

ISSN: 2581-8341

Volume 04 Issue 08 August 2021

DOI: 10.47191/ijesrr/V4-i8-07, Impact Factor: 5.825

IJCSRR@ 2021

www.ijesrr.org

21. Rodger, S. C. and A. W. Johnson (2005). "The Impact of Residence Design on Freshman Outcomes: Dormitories Versus Suite-Style Residences." Canadian Journal of Higher Education 35(3): 83-99.

22. Saffarpoor, S., et al. (2011). "The effectiveness of solution-focused brief therapy on increasing social adjustment of female students residing in Tehran University dormitories." International Journal of Psychology and Counselling 3(2): 24-28.

23. Sharma, B. (2012). "Adjustment and emotional maturity among first year college students." Pakistan Journal of Social and Clinical Psychology 9(3): 32-37.

24. Smith, M. L. (2008). The transition to university: Adaptation and adjustment.

25. Souza, M. T. d., et al. (2010). "Integrative review: what is it? How to do it?" Einstein (São Paulo) 8(1): 102-106.

26. Tao, S., et al. (2000). "Social support: Relations to coping and adjustment during the transition to university in the People's Republic of China." Journal of adolescent research 15(1): 123-144.

27. Taylor, Z. E., et al. (2014). "Transitioning from high school to college: Relations of social support, ego-resiliency, and maladjustment during emerging adulthood." Emerging Adulthood 2(2): 105-115.

28. Thurber, C. A. and E. A. Walton (2012). "Homesickness and adjustment in university students." Journal of American college health 60(5): 415-419.

29. Torraco, R. J. (2005). "Writing integrative literature reviews: Guidelines and examples." Human resource development review 4(3): 356-367.

30. Urani, M. A., et al. (2003). "Homesickness in Socially-Anxious First Year College Students." College Student Journal 37(3): 392-399.

31. Utari, R., et al. (2014). "Pembentukan Iklim Sosial-akademik Di Asrama Mahasiswa." Jurnal Penelitian Humaniora 19(1).

32. Wintre, M. G. and M. Yaffe (2000). "First-year students' adjustment to university life as a function of relationships with parents." Journal of adolescent research 15(1): 9-37.

Cite this Article: Mukhroni, Sowiyah Sowiyah, Hasan Hariri (2021). Transition and Adjustment of First-Year Student College in Dormitory: A Literature Review. International Journal of Current Science Research and Review, 4(8), 895-905 